\title{
High crossectomy without vascular sectioning vs classic saphenectomy. Randomized clinical trial: analysis of recurrent varicose
}

\author{
Crosectomía alta sin sección vascular frente a safenectomía clásica. \\ Ensayo clínico aleatorizado: análisis de la recidiva varicosa
}

\author{
I. Cañizares Díaz ${ }^{1}$, T. Arrobas Velilla ${ }^{2}$, M. Illescas Rodríguez ${ }^{1}$, J. M. Martín Martín ${ }^{1}$
}

\begin{abstract}
Background. This study was designed with the purpose of defining a new surgical procedure for varicose veins surgery and to be compared with classic crossectomy in terms of reducing varicose recurrence rate.

Material and methods. Double-blind randomized clinical trial. For easy access, we selected 150 patients who came to Phlebology Unit Consultation, meeting the criteria for inclusion in the study with their informed consent, to be included in a study group using random table numbers table numbers. Group 1: (CS) Saphenectomy classic 75 patients. Group 2: (HCWVS) High crossectomy without vascular sectioning. In both groups the monitoring was conducted at 12 and 24 months by Eco-Doppler study.
\end{abstract}

Results. The incidence of varicose recurrence at 12 months follow up was $69.3 \%$ in the group of patients undergoing CS, while in the group receiving HCWVS was $29.3 \%$ ( $p<0.0001$ ). These differences, though minor, remain statistically significant at 24 months of evolution (76\% vs. $48 \%, p=0.0004$ ). The most common type of recurrence is the type I with statistically significant differences at 12 and 24 months.

Conclusions. High crossectomy without vascular section has a global recurrence probability significantly lower than with classic saphenectomy at 12 months ( $29.3 \%$ vs. $69.3 \%$ ), which remains, though smaller, statistically significant at two years of evolution (48\% vs. $76 \%$ ). The recurrence reticular type rate is significantly lower in the group of patients undergoing high crossectomy without vascular section compared to those undergoing saphenectomy with classic crossectomy.

Key words. Chronic venous disease, Neovascularization, Recurrent Varicose After Surgery (REVAS), Saphenectomy, Varicose veins.

\section{RESUMEN}

Fundamento. El presente estudio fue diseñado con el propósito de definir un nuevo procedimiento quirúrgico para la cirugía de las varices y compararlo con estudios de crosectomía clásica en términos de reducir la tasa de recidiva varicosa.

Material y métodos. El estudio presentado es un ensayo clínico aleatorizado, doble ciego. Para facilitar el acceso se seleccionaron 150 pacientes que acudieron a consulta Unidad de Flebología, que facilitaron su consentimiento cumpliendo los criterios de inclusión. Se hicieron dos grupos: Grupo 1: safenectomía clásica (CS); 75 pacientes. Grupo 2 : crosectomía alta sin sección vascular (HCWVS) . En ambos grupos el seguimiento se realizó a los 12 y 24 meses por estudio eco- Doppler.

Resultados. La incidencia de recidiva varicosa a los 12 meses de seguimiento fue de $69,3 \%$ en el grupo de pacientes sometidos a safenectomía clásica , mientras que en el grupo que recibió HCWVS fue 29,3\% ( $<<0,0001$ ). Estas diferencias, aunque menores, siguen siendo estadísticamente significativa a los 24 meses de evolución (76\% vs $48 \%, p=0,0004)$. El tipo más común de recurrencia es del tipo I, con diferencias estadísticamente significativas a los 12 y 24 meses.

Conclusiones. La crosectomía alta sin sección vascular tiene una probabilidad global de recurrencia significativamente menor que la safenectomía clásica a los 12 meses (29,3 \% frente a $69,3 \%$ ) , que sigue siendo , aunque más pequeña, estadísticamente significativa a los dos años de evolución ( $48 \%$ vs $76 \%$ ) . La tasa de recurrencia del tipo reticular es significativamente menor en el grupo de pacientes sometidos a alta crosectomía sin sección vascular que en los sometidos a safenectomía clásica.

Palabras clave. Enfermedad venosa crónica. Neovascularización recurrente varicosas. (REVAS). Safenectomía. Crosectomía.
1. Hospital Blanca Paloma. Huelva. España.

2. Profesora de la Facultad de Medicina de la Universidad Autónoma de Chile.

Recepción: 28 de mayo de 2013

Aceptación provisional: 4 de julio de 2013

Aceptación definitiva: 18 de julio de 2013

\author{
Correspondencia: \\ Teresa Arrobas \\ 5 poniente 1670 \\ Talca \\ Chile \\ teresaarrobasvelilla@hotmail.com
}




\section{INTRODUCTION}

Between $10 \%$ and $20 \%$ of the world population suffer from varicose veins in the lower extremities ${ }^{1}$. This has an important impact on health care costs and the leaves of absence are associated to pathology with a high prevalence.

According to the Clinical practice guidelines of the Society for Vascular Surgery and the American Venous Forum, the ideal treatment is surgery ${ }^{2}$. There have been multiple surgical procedures which have been put in place to treat Chronic Venous Insufficiency, from the proximal ligature of the saphenofemoral junction or in combination with phlebectomy, sclerotherapy or saphenectomy. The best results have been demonstrated extracting the saphenous vein versus a simple crossectomy with or without phlebectomy ${ }^{3,4,5,6,7}$.

Other surgical procedures have been added to the therapeutic arsenal of varicose veins surgery, such as Muller's ambulatory phlebectomy in $1966^{8}$, the CHIVA cure, the echo Doppler guided sclerosis with liquid ${ }^{9}$ or foam $^{10}$, the subfascial endoscopic ligature of perforant veins ${ }^{11}$, more recently, endoluminals techniques of radiofrequency and endovenous laser ablation ${ }^{12}$, or the new technique for ablation with vaporized water ${ }^{13}$. None have proven to be more effective than the crossectomy with saphenectomy, because high percentage of recurrence after treatment (7 to $77 \%$ ) is the principal problem of all surgical procedures for the treatment of varicose veins ${ }^{1,14}$.

In the nineties, Vin and Chleir ${ }^{13}$, described a new technique called 3-S (saphenous section sclerotherapy), which has diminished the recurrence of varicose veins, particularly the proximal venous segment. This technique consists of sclerosing the saphenous femoral junction and the saphenous distal trunk, also sectioning the same about $10 \mathrm{~cm}$ from the saphenous femoral junction. This procedure has reduced the recurrence of the proximal levels and the neoangiogenesis, but not distal recurrences that describe a higher rate than the classic saphenectomy ${ }^{15}$.

Subsequently in this research, there have been implemented procedures with sclerosis of the saphenous femoral junction associated with saphenectomy and preservation of the side branches laterals, showing a reduction in the overall rate of recurrence, particularly those of a reticular type ${ }^{16}$.

However, many authors have associated the recurrence of the proximal end with an insufficiently high crossectomy, leaving untreated some side-branches, this being relatively opposite of what is being claimed by other authors ${ }^{17,18}$.

This reasoning leads us to believe in a high crossectomy to decrease the recurrence rate of the proximal truncular type and a procedure that does not cause the subsequent endothelial cell implantation and therefore neoangiogenesis, etiology of recurrent proximal reticular type.

We describe a surgical procedure called High Crossectomy without Vascular sectioning (HCWVS) that helps to ligature the saphenous arch at its junction with the femoral vein as well as all its side-branches without being subject to sectioning, associated with a classic saphenectomy, and compared with classic crossectomy with ligature and sectioning of all the side-branches and the stripping of the great saphenous vein.

Our working hypothesis is that the technique HCWVS produces a reduction in the rate of proximal recurrences, particularly the reticular varicose type, in comparison with the surgical approach with ligature and sectioning of the side-branches veins that is performed in classic surgery.

The aim of this study is to compare two techniques and succeed at being able to diminish the high rate of recurrence that occurs after classic surgery (stripping), especially reticular recurrence rate that originates in the arch of the saphenous vein.

\section{PATIENTS AND METHODS}

Upon approval by the medical ethics committee and informed consent of patients, a double-blind controlled trial was conducted in patients between 26 and 70 years of age with chronic venous insufficiency stage $\mathrm{C} 2 \mathrm{~b}$ or higher. 
The randomization carried out by means of tables of random numbers was obtained by informatics system. The above mentioned sequence was generated by the department of the pharmacology hospital and it was only known by the pharmaceutical chief. Just before the intervention she phones the surgeons to tell the surgical technique. The sequence was blind to all of the members of the equipment up to the moment of the intervention. Neither the ultrasonographer, nor the patient knew the performed technique.

During 9 months and prior calculation of sample size, 150 patients were selected from those who came to the Vein Surgery Consultation with chronic venous insufficiency. Eligible patients were assigned random numbers which identified the study groups: classic saphenectomy (CS) or saphenectomy with high crossectomy without vascular sectioning (HCWVS).

Venous Doppler ultrasound was scheduled for all patients at 12 and 24 months after surgery. In this examination, recurrent varicose arch level and type was determined.

All patients were informed of their inclusion in the study, consenting in writing for inclusion in it. Excluded were patients without surgical indication due to their age (over 70), history of deep vein thrombosis or thrombophilia diagnosis, previous surgery of CVI on the extremity to be treated, congenital varicose veins, or anesthetic contraindications. In our department, patients over 70 are treated with conservative therapies (Phlebosclerosis and elastocompression)

\section{Surgical procedure}

Group 1: Classic Saphenectomy CS ( $\mathrm{n}=$ 75). Incision at the groin crease. Dissection with electrocautery of the presaphenous lymphatic tissues. Ligature and sectioning of side branches of the sapheno-femoral junction. Ligature, sectioning and point booster transfixed at the arch. Phlebectomies of collateral branches by the Müller method. Ending with stripping of the saphenous vein. Compressive elastic bandage.
Group 2: HCWVS High Crossectomy without Vascular sectioning $(\mathrm{n}=75)$. Incision at the groin crease. Dissection of lymphatic presaphenous tissue without electrocautery or sectioning. Sapheno-femoral junction skeletonization with identification of all the side branches and its junction with the femoral vein. Ligature of the great saphenous vein at the sapheno-femoral junction and the same thread ligature of all side branches, ending with another distal invaginating saphenous ligature to them and without sectioning of side-branches veins (Fig. 1). Catheterization at the supramalleolar saphenous vein with the flebo-stripper, which is externalized at the groin about $5 \mathrm{~cm}$ distally of the sapheno-femoral junction. Phlebectomies of collateral veins by Müller method. Finally stripping of the saphenous vein and compressive elastic bandage.

All patients were operated by the same surgeon.

\section{Anesthetic Technique}

In both groups surgery was performed with epidural anesthesia. The protocol of surgery of varicose veins includes thromboembolic prophylaxis the day before surgery with enoxaparin, administered subcutaneously, a prophylactic dose $(0.5 \mathrm{mg} / \mathrm{kg}$ body weight) and during twenty days after surgery at the same dose, and antibiotic prophylaxis first-generation cephalosporin an hour before surgery.

\section{Venous Eco Doppler}

The radiologist who performed Eco Doppler ultrasound examinations, both before surgery and at 12 and 24 months of it was always the same, and did not know to which group the patient belonged.

The scanner used was a Siemens G40 with a probe of $8.5 \mathrm{MHz}$, and the study was performed in supine and standing positions. Reflux was considered positive when it was over a second in duration. Varicose recurrences were classified as reticular or truncular based on their diameter. 


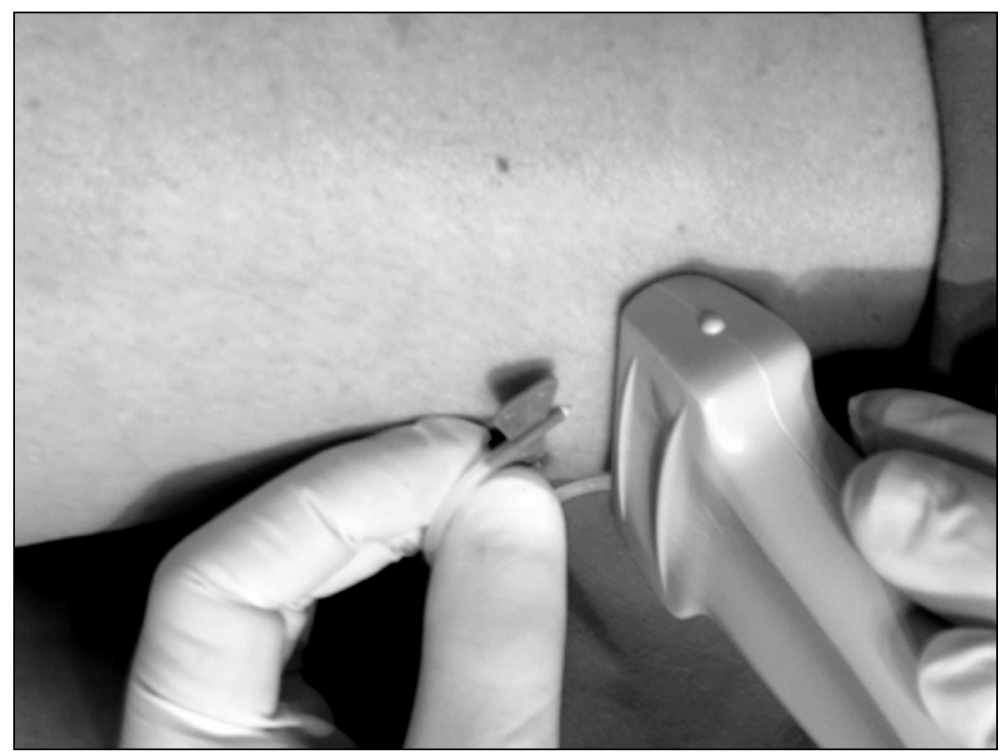

Figure 1.

Ultrasound guided.
The Color Doppler study was focused in the previous site of the saphenous femoral junction. Procedures such as the Valsalva maneuver with amplified zoom were utilized to detect tributary veins of the Scarpa triangle.

Classification of neovascularisation described by DeMaeseneer were used in this study ${ }^{13,14,15}$. If no new vessels have been connected to the common femoral vein, grade 0 was determined. If a new vessel was found in the area explored, and its diameter is less than $3 \mathrm{~mm}$. and duration of reflux less than 1 second, it was determined grade 1 . And level 2 is reserved for the veins with a diameter $>3 \mathrm{~mm}$, superior reflux, $1 \mathrm{~mm}$ in diameter and communicating with superficial varicosities in the thigh.

\section{Statistical analysis}

The statistical program used was SPSS version 1.8. The description of the continuous variables was done based in the median, standard deviation, median, interquarter range. For nominal variables we used perceptual distributions.

As a measure of epidemiologic rate, risk incidence and confidence Interval was cal- culated to be $95 \%$ and in association force relative risk and confidence Interval was 95\% also considering group 1 as a control group (CS).

The results between both groups were analyzed by the significant statistic test: Student test for continuous variables, distributed $\chi 2$ for the nominal variables. We prior established a statistic significant level $\alpha=0,05$.

Table 4. According to the premises included in table 4 and after consulting the tables of the sample size calculation in order to compare the proportions, the number of patients to include in every group is 72 (total of 144).

Based on previous studies conducted at the center, the estimated drop-out rates in patient during the follow-up is $1 \%$ at two years. So we decided to increase the number of patients per group to 75 . In the present study, we didn't had any drop-out patients during the follow-up.

\section{RESULTS}

All patients were followed on an outpatient basis for 24 months. No clinical evidence exists of major complications such 
as deep vein thrombosis or pulmonary embolism.

In table 5, we present the flow chart recommended by the CONSORT statement website, in which you can see the number of patients seen during 9 months, who met a inclusion criteria and those who do not and control of the follow-up in both study arms.

Demographic analysis of the sample does not highlight significant differences in both groups, the mean age group 1 (CS) was 54 years and 55 for the 2 ( HCWVS). The ratio of male to female in group 1 (CS) was $11 / 64$ while for the 2 (HCWVS) was $13 / 62$.

Referring to the clinic that encourages consultation with the Phlebology Unit, the main complaint in both groups was the feeling of tiredness and heaviness in $41 \mathrm{pa}-$ tients in group 1 and 37 in group 2. Aesthetics was the least complaint with 5 cases in group 1 and 6 in group 2.

In group 1 the evolution of the disease varied between 2 and 13 years with a mean of 8 and in group 2 ranged from 4 to 15 with an average of 7 years.

The diameter at the saphenous arch was measured in both groups. The measurement varied between 4 and $15 \mathrm{~mm}$ in both groups, with an average of 6.2 in group 1 and 6.1 in group 2.

Attached demographic data and preoperative clinical testing group in Table 1.

Table 1. Clinical and demographic pre-operative data

\begin{tabular}{lcc}
\hline & $\begin{array}{c}\text { GROUP I } \\
\text {-CS- } \\
\text { N=75 }\end{array}$ & $\begin{array}{c}\text { GROUP II } \\
- \text { HCWVS- } \\
\text { N=75 }\end{array}$ \\
\hline Age (median) & 54 & 55 \\
\hline Ratiomale/female & $11 / 64$ & $13 / 62$ \\
\hline Pain & $22(29.3 \%)$ & $28(37.3 \%)$ \\
\hline Heaveness/tireness & $41(54.6 \%)$ & $37(49.3 \%)$ \\
\hline Complications & $7(9.3 \%)$ & $4(5.3 \%)$ \\
\hline Aesthetics & $5(6.6 \%)$ & $6(8 \%)$ \\
\hline Evolution (years) & $8(2-13)$ & $7(4-15)$ \\
\hline Saphenous diameter (mm.) & $6.2(4-15)$ & $6.1(4-15)$ \\
\hline
\end{tabular}

Table 2 shows the ultrasound data obtained at 12 months of surgery, in which details the type of recidivated vein. As seen in this table, the recurrence rate is significantly lower in the group of patients treated with HCWVS. Also include a significantly lower incidence of type 1 recurrence varicose veins in the group of patients treated with HCWVS compared to those treated with classic saphenectomy.

Table 2. Results of the ecodoppler study done at 12 months

\begin{tabular}{cccc}
\hline & Group I & Group II & P \\
\hline Total Recurrences & $52(69.3 \%)$ & $22(29.3 \%)$ & 0.0001 \\
\hline Recurrence Type I (diameter $<3 \mathrm{~mm})$ & $33(44.0 \%)$ & $5(6.6 \%)$ & 0.0001 \\
\hline Recurrence Type II (diameter $>3 \mathrm{~mm})$ & $19(25.3 \%)$ & $17(22.6 \%)$ & 0.7 \\
\hline
\end{tabular}


All the data obtained at 24 months of evolutions shows minor incidence in recurrence for patients with high crossectomy without sectioning vessel compared with patients who had done classic crossectomy (48\% VS 76\% p=0,0004), been in this case the most frequent recurrence type II, but there was not statistically significant difference between both groups. There was more recurrence type I in the group of patients that had done classic crossectomy, in this case the difference was statistically significant $(34,6 \%$ VS 13,3\%; $\mathrm{p}=0,0022)$ (Table 3).

Table 3. Results of the ecodoppler study done at 24 months

\begin{tabular}{lccc}
\hline & Group I & Group II & P \\
\hline Total Recurrences & $57(76.0 \%)$ & $36(48.0 \%)$ & 0.0004 \\
\hline Recurrence Type I (diameter $<3 \mathrm{~mm})$ & $26(34.6 \%)$ & $10(13.3 \%)$ & 0.0022 \\
\hline Recurrence Type II (diameter $>3 \mathrm{~mm})$ & $31(41.3 \%)$ & $26(34.6 \%)$ & 0.4 \\
\hline
\end{tabular}

Table 4. For the calculation of the sample size the following considerations were born in mind

- The contrast of hypothesis is considered bilateral.

- We consider a risk of committing a mistake type I $(\alpha)$ of $5 \%$.

- We consider a risk of committing a mistake type II (ß) of $10 \%$.

- The statistical power of the study (1-ß) is $90 \%$.

- We estimated, a priori, a proportion of recurrence in the group I (classic crossectomy) of $45 \%$ and in the group II (crossectomy without vascular sectioning) of $20 \%$.

- The difference or magnitude of the difference to detecting in the study is $25 \%$.

- The variability of the variable of response is very wide, ranging between 7 and $77 \%$ according to the consulted bibliography.

\section{DISCUSSION}

The therapeutic arsenal for chronic venous insufficiency has increased in recent years with new procedures such as radiofrequency and endolaser ablation, polidocanol foam sclerosis and crossectomy among others, but today, the gold standard of therapy for chronic venous insufficiency is the great saphenectomy ${ }^{4,6}$, complete or proximal to safeno-phemoral junction ${ }^{15}$, to prevent saphenous nerve injury, and it is the therapeutic process that compares all new procedures introduced in the surgical treatment of the chronic venous insufficiency. The rate of recurrence after venous surgery could be the order of $50 \%$ at 5 years, ranging, according to authors, between 15 and $70 \%{ }^{15}$. These data relate to follow up based on clinical examination, with or without continuous Doppler, and less frequently involving the use of echoDoppler. It is obvious that if we standardize the results we consistently use the color Doppler, bearing in mind that this will yield higher rates of varicose recurrence compared to studies where clinical exploration was used.

It is important to stress that recurrences can be topographically classified into proximal to the saphenous-femoral and distal to it, referring the latter to be produced at a distance and with no continuing relationship with the same ${ }^{17}$. Referring to the first one, proximal recurrence, Gorny and Blanchemaison postulated that its causes may be hemodynamic and anatomical ${ }^{16}$. There are two anatomical forms of proximal recurrences: recurrence of truncular saphenous neoarch and recurrence reti- 
Tabla 5. CONSORT 2010 Flow Diagram

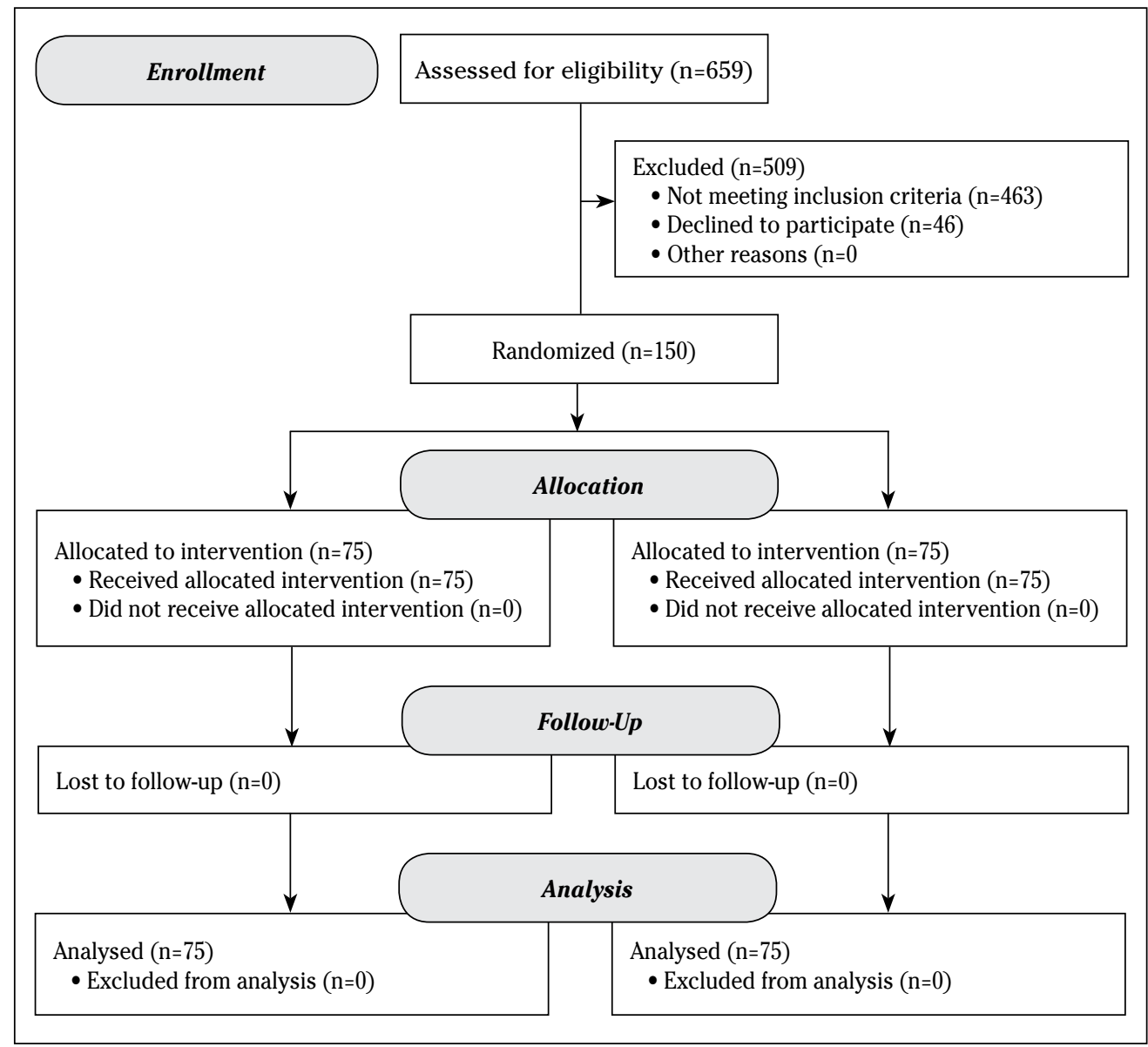

cular neovascularization. The first corresponds to grade 2 of DeMaeseneer and the second one to grade 1 . The rationale for proximal recurrences of grade 2 is usually an incomplete high crossectomy ${ }^{18}$. With regard to proximal type 1 recurrences, there are several assumptions that would justify their appearance, from the surgical section of the side branches veins ${ }^{17,19,20,21,22,25,26}$, to persistence in situ after surgery of a distal incompetent venous system after correct crossectomy that through neoangiogenesis, would recruit parietal veins, lymph node and the vasa vasorum of the saphenous vein, and finally, re-establish contact with the deep venous system ${ }^{16}$. Gillet called this phenomenon as "recruitment aspira- tion effect" ${ }^{\prime 23}$. That is whatever the quality of crossectomy and stripping, if distal incompetent veins are left, this will promote reticulated recurrence. Glass has shown that reducing the number of sectioned side branches just to the medial arch, and replacing the simple ligature of the arch by stripping, there is no neoangiogenesis (25\% to $1 \%)^{17}$. But there are not reference to the truncular recurrence that always accompanies incomplete or not sufficiently high crossectomies $^{24,25,26,27}$.

In conclusion, we can say that according to the literature the main cause of proximal recurrence type 2 is the incomplete or no high crossectomy and the type 1 due to endothelial neoangiogenesis contact 
and the presence of incompetent distal venous bed.

This study shows that the high crossectomy without sectioning vessels is a very simple surgical procedure without additional costs and minimally invasive to the patients; that offers to the doctor and the patient an important reduction in proximal and reticular recurrence, generating a minor recurrence varicose after surgery.

Consistent with this are the results obtained in this study where the overall recurrence rate at one year and two years is significantly lower in the group undergoing HCWVS (29.3\% y 48\%) than in the group undergoing saphenectomy with classic crossectomy CS (69\% y 76\%).

Contrary to what some authors postulate on incomplete crossectomy ${ }^{17}$, we believe it necessary to interrupt venous flow in all the side-branches of the saphenous arch, by sectioning veins or doing ligature veins. In our study we can see that no significant differences between type 2 recurrence rate in either of the two groups (First year: Group CS: 25\%, Group HCWVS: 22\%. Second year: Group CS: 41\%, Group HCWVS: 34\%).

On the opposite, there are different rate of type 1 recurrence varicose (reticular varicose vein) between the saphenectomy with classic crossectomy and saphenectomy with crossectomy without vascular sectioning (44\% and 6.6\%, the first year and 34\% and $13 \%$ the second one respectively). There are several circumstances that would explain these data. First, the surgical approach for arch collateral veins reticular relapse occurs, possibly because of a neoangiogenesis ${ }^{1,13,16,21}$. The absence of side branches section prevents vascular endothelial cell seeding during surgery and the use of blunt dissection, avoiding sectioning lymph ducts in the triangle of Scarpa, prevents the development of lymph nodal blade which does happen after ligature of the saphenofemoral junction and its side branches, and the consequent alteration of drainage ${ }^{17}$.

Low rate of recurrence type 1 in other surgical techniques that replace crossectomy by sclerotherapy, can be justified because of avoiding vascular sectioning and impairing lymphatic drainage of the groin $\operatorname{area}^{28}$. The principal disadvantage of this technique is the high rate of revascularization which is present in the large venous trunks after sclerotherapy ${ }^{29}$.

The statistical study has shown that the saphenectomy with crossectomy without vascular sectioning has a probability of overall recurrence a year significantly lower than the saphenectomy with crossectomy (30\% versus $70 \%$ ), which is kept in the statistical significance at two years; and the reticular recurrence rate of type 1 is significantly lower in the group of patients undergoing saphenectomy with crossectomy without vascular sectioning versus those that were treated with saphenectomy with classic crossectomy.

We believe that the saphenectomy with crossectomy without vascular sectioning is the appropriate procedure to treat varicose veins by reducing the relapse rate or reticular type 1 and maintaining the principles of classic surgery to reduce the recurrence rate type 2 or truncular.

It would be recommended to implement this technique with procedures based in saphenous sclerosis with foam of the saphenous femoral junction, in order to assess the recurrence rate of type 2 or truncular.

\section{BIBLIOGRAPHY}

1. Turton EPL, Scout DJA, Richards SP, Weston MJ, BerIIDGE DC, Kent PJ, et al. Duplex-derived evidence reflux after varicose vein surgery: neoreflux or neovascularisation? Eur J Vasc Endovasc Surg 1999; 17: 230-233.

2. Gloviczki P, Comerota AJ, Dalsing MC, EkLof BG, Gillespie DL, Gloviczki ML, et al. The care of patients with varicose veins and associated chronic venous diseases: clinical practice guidelines of the Society for Vascular Surgery and the American Venous Forum. J Vasc Surg 2011; 53 (5 Suppl): 2S-48S.

3. Rutgers PH, KitslaAr PJEHM. Randomized trial of stripping versus high ligature combined with sclerotherapy in the treatment of incompetent greater saphenous vein. Am J Surg 1994; 168: 311-315.

4. SARIN S, ScurR JH, Smith PDC. Stripping of the long saphenous vein in the treatment of primary varicose veins. Br J Surg 1994; 81: 14551458. 
5. Frings N, Frings A-C, Tran P, Schubert R. Reduction of neoreflux at the saphenofemoral junction by extensive crossectomy.Phlebologie 2010; 39: 325-328.

6. Winterborn RJ, EARnSHAW JJ. Crossectomy and great saphenous vein stripping. J Cardiovasc Surg (Torino) 2006; 47: 19-33.

7. Geroulakos G, Davies AH. Crossectomy and foam: has it got a role in the contemporary management of primary varicose veins? Phlebology 2009; 24: 1-2.

8. MüLLER R. Traitement des varices par la phlébectomie ambulatiore. Societé Française de Phlébologie 1966; 4: 277-279.

9. Min RJ, Navarro L. Transcatheter duplex ultrasound-guided sclerotherapy for treatment of greater saphenous vein reflux: preliminary report. Dermatol Surg 2000; 26: 410-414.

10. Hamel-Desnos C, Desnos P. L'echo-sclérothérapie à la mousse en 2004: technique de la ponction-injection directe. Phlébologie 2004; 57: 289-300.

11. CañIzares Díaz I, Juan Fernandez A. Insuficiencia de venas perforantes en miembros inferiores. Ligadura subfascial endoscópica. Cirugía Española 2002; 71: 63-67.

12. Bonte F, Vuylsteke M. New treatments for varicose veins. Tijdschrift voor Geneeskunde 2010; 66: 874-880.

13. Vin F, Chleir F. Section sclérothérapie des grandes veines saphènes incontinentes. Technique 3S: résultats à 5 ans. Phlébologie 2002; 5: 59-63.

14. Rewerk S, Noppeney T, Nüllen H, Winkler M. Neoangiogenesis as cause of recurrence after crossectomy of primary varicose veins. Gefasschirurgie 2008; 13: 130-134.

15. Guex JJ, Puppinck P, Nicolini P. Récidives aprés chirurgie des varices des membres inférieurs. Problèmes posés, fréquence, coût. Phlébologie 1998; 51: 393-396.

16. Blanchemaison P, Gorny P. Le guide des veines. Connaissance et santé. Paris: Éditions Denoël; 1991; 59.

17. GLASS GM. Prevention of recurrent saphenofemoral incompetente through neovascularization after surgery for varicose veins. Br J Surg 1989; 76: 1210.

18. Donati M, Gandolfo L, Brancato G, Privitera A, Donati A. Recurrent varicose veins due to neovascularisation: can they be prevented? Chir Ital 2008; 60: 83-90.
19. De Maeseneer MG, Vandenbroeck CP, Hendriks JM, LAuwers PR, VAN SchIL PE. Accuracy of duplex evaluation one year after varicose vein surgery to predict recurrence at the sapheno-femoral junction after five years. Eur $\mathrm{J}$ Vasc Endovasc Surg 2005; 29: 308-312.

20. De Maeseneer MG, Ongena KP, Van den Brande F, Van Schil PE, De Hert SG, Eyskens EJ. Duplex ultrasound assessment of neovascularisation after saphenofemoral or saphenopoliteal junction ligature. Phlebology 1997; 12: $64-68$.

21. De Maeseneer MG, Tielliu IF, Van Schil PE, De HERT SG, Eyskens EJ. Clinical relevance of neovascularisation on duplex ultrasound in the long-term follow-up after varicose vein operation. Phlebology 1999; 14: 118-122.

22. Coget JM, Merlen JF. Réflexions à propos des varices récidivantes. Phlébologie 1985; 35: 529-532.

23. GILLET JL. Les récidives variqueuses postchirurgicales. Indications thérapeutiques du traitement medical. Phlebologie 1998; 51: 489-493.

24. Franco G. Exploration ultrasonographique des récidives variqueuses post-chirurgicales. Phlébologie 1998; 51: 403-413.

25. SAVel'Ev VS, Kirienko AI, Zolotukhin IA, AndrilasHKIN AV. Unadequate ostial ligature of the great saphenous vein as the cause of varicose disease reccurence. Angiol Sosud Khir 2007; 13: 73-77.

26. Bartos J Jr, Bartos J. Causes of recurrencies following procedures for varicose veins of the lower extremities. Rozhl Chir 2006; 85: 293-295.

27. Joshi D, Sinclair A, Tsui J, SARIN S. Incomplete removal of great saphenous vein is the most common cause for recurrent varicose veins. Angiology 2011; 62: 198-201.

28. Arenas-Ricart J, Sellés-Dechent R, Ballester-IbÁÑez C, PÉrez-Monreal J, González-Vila S, Ruiz-Del CAStillo J. Cirugía clásica frente a 3-S safenectomía para el tratamiento de las varices del miembro inferior. Cir Esp 2006; 79: 370-374.

29. Darvall KA, Bate GR, Adam DJ, Silverman SH, Bradbury AW. Duplex Ultrasound Outcomes following Ultrasound-guided foam sclerotherapy of symptomatic recurrent great saphenous varicose veins. Eur J Vasc Endovasc Surg 2011; 42: 107-114. 
